University of Nebraska - Lincoln

DigitalCommons@University of Nebraska - Lincoln

\title{
Arsenic(III) Oxidation and Arsenic(V) Adsorption Reactions on Synthetic Birnessite
}

\author{
Bruce A. Manning \\ San Fancisco State University, bmanning@sfsu.edu \\ Scott E. Fendorf \\ Stanford University \\ Benjamin Bostick \\ Stanford University \\ Donald L. Suarez \\ USDA-ARS
}

Follow this and additional works at: https://digitalcommons.unl.edu/usdaarsfacpub

Part of the Agricultural Science Commons

Manning, Bruce A.; Fendorf, Scott E.; Bostick, Benjamin; and Suarez, Donald L., "Arsenic(III) Oxidation and Arsenic(V) Adsorption Reactions on Synthetic Birnessite" (2002). Publications from USDA-ARS / UNL Faculty. 503.

https://digitalcommons.unl.edu/usdaarsfacpub/503

This Article is brought to you for free and open access by the U.S. Department of Agriculture: Agricultural Research Service, Lincoln, Nebraska at DigitalCommons@University of Nebraska - Lincoln. It has been accepted for inclusion in Publications from USDA-ARS / UNL Faculty by an authorized administrator of DigitalCommons@University of Nebraska - Lincoln. 
Arsenic(III) Oxidation and Arsenic(V) Adsorption Reactions on Synthetic Birnessite

BRUCE A. MANNING,*,† SCOTTE. FENDORF, $\neq$ BENJAMIN BOSTICK, $\neq A N D$ DONALD L. SUAREZ§

Department of Chemistry and Biochemistry, San Francisco State University, San Francisco, California 94132, Department of Geological and Environmental Sciences, Stanford University, Palo Alto, California 94305, and USDA-ARS U.S. Salinity Laboratory, 450 West Big Springs Road, Riverside, California 92507

The oxidation of arsenite (As(III)) by manganese oxide is an important reaction in both the natural cycling of $A s$ and the development of remediation technology for lowering the concentration of dissolved As(III) in drinking water. This study used both a conventional stirred reaction apparatus and extended X-ray absorption fine structure (EXAFS) spectroscopy to investigate the reactions of $A s(I I I)$ and $\mathrm{As}(\mathrm{V})$ with synthetic birnessite $\left(\mathrm{M} \mathrm{nO}_{2}\right)$. Stirred reactor experiments indicate that $\mathrm{As}(\mathrm{III})$ is oxidized by $\mathrm{M} \mathrm{nO}_{2}$ followed by the adsorption of the $A s(V)$ reaction product on the $\mathrm{MnO}_{2}$ solid phase. The As(V)-Mn interatomic distance determined by EXAFS analysis for both As(III)- and As(V)treated $\mathrm{MnO}_{2}$ was $3.22 \AA$, giving evidence for the formation of $\mathrm{As}(\mathrm{V})$ adsorption complexes on $\mathrm{M} \mathrm{nO}_{2}$ crystallite surfaces. The most likely $\mathrm{As}(\mathrm{V})-\mathrm{MnO}_{2}$ complex is a bidentate binuclear corner sharing (bridged) complex occurring at $\mathrm{M} \mathrm{nO}_{2}$ crystallite edges and interlayer domains. In the As(III)treated $\mathrm{MnO}_{2}$ systems, reductive dissolution of the $\mathrm{MnO}_{2}$ solid during the oxidation of As(III) caused an increase in the adsorption of $\mathrm{As}(\mathrm{V})$ when compared with $\mathrm{As}(\mathrm{V})$-treated $\mathrm{MnO}_{2}$. This suggested that $\mathrm{As}$ (III) oxidation caused a surface alteration, creating fresh reaction sites for $A s(V)$ on $\mathrm{MnO}_{2}$ surfaces.

\section{Introduction}

The environmental and human health impacts of elevated concentrations of As in ground water have received increased attention because of its toxicity (1-3). Thepredominantforms of As in soil and water are as inorganic arsenate (As(V)) and arsenite (As(III)) (4-7). Under oxidizing and aerobic conditions, the As(V) species predominates and exists as oxyanions of arsenic acid $\left(\mathrm{H}_{2} \mathrm{AsO}_{4}{ }^{-}\right.$and $\left.\mathrm{HAsO}_{4}{ }^{2-}\right)$ (8). The As(III) species exists as undissociated arsenious acid $\left(\mathrm{H}_{3} \mathrm{AsO}_{3}{ }^{0}\right)$ below $\mathrm{pH}$ 9.2 (9) and predominates under reducing conditions in sediments, groundwater, and soils (8-11). TheAs(III) species is substantially more toxic than $\operatorname{As}(\mathrm{V})(12,13)$ and tends to be more weakly bound to soils than $\mathrm{As}(\mathrm{V})$. This latter phenomenon is probably due to a combination of factors,

* Corresponding author phone (415) 338-1292; fax: (415) 2764759; e-mail: bmanning@sfsu.edu.

+ San Francisco State University.

‡ Stanford University.

§ USDA-ARS U.S. Salinity Laboratory. including concomitant reductive dissolution of Fe oxides which adsorb both $\mathrm{As}(\mathrm{III})$ and $\mathrm{As}(\mathrm{V})$ and the tendency for As(III) to adsorb more weakly to most aluminum oxide and aluminosilicate soil minerals than $\mathrm{As}(\mathrm{V})(14,15)$.

An important reaction in the environmental fate of As(III) is heterogeneous oxidation on soil mineral surfaces (16-21). Manganeseoxides are extremely important minerals because they readily oxidize many reduced species such as As(III) (18-24), Co(II) $(25,26), \mathrm{Cr}(\mathrm{III})(27)$, and organic molecules $(28,29)$. The crystalline structures of $\mathrm{Mn}$ oxides are of environmental interest because of the adsorptive and oxidative capabilities of these minerals. Synthetic birnessite has been extensively investigated because it is representative of many naturally occurring manganese oxide materials (18$21,25,30,31)$. The Na- and K-substituted birnessite are phyllomanganates, possessing layered sheet structures with edge-sharing $\mathrm{Mn}$ octahedra $(25,30)$. These materials have been described as nearly vacancy-freelayers of $\mathrm{Mn}$ octahedra influenced byJahn-Teller distortion when $\mathrm{Mn}$ (III) substitutes for $\mathrm{Mn}(\mathrm{IV})$. An ordered distribution of $\mathrm{Mn}(\mathrm{III})$-rich rows, interlayer counterions $\left(\mathrm{Na}^{+}\right.$or $\left.\mathrm{K}^{+}\right)$, and octahedral vacancies completes the crystal structure $(25,30)$. The average chemical formula for sodium birnessite has been given as $\mathrm{Na}_{0.333}\left(\mathrm{Mn}_{0.722}^{4+} \mathrm{Mn}_{0.222}^{3+} \mathrm{Mn}_{0.055}^{2+}\right) \mathrm{O}_{2}$ (30), indicating a partial negative charge per unit cell. Moore et al. (18) showed that the $\mathrm{O} / \mathrm{Mn}$ ratio for most synthetic birnessites is near 2 . For simplicity, the birnessitechemical formula will besimplified to $\mathrm{MnO}_{2}$ in this paper.

Details about the chemical mechanism of As(III) heterogeneous oxidation by birnessite are emerging (18-21). Oxidation of $\mathrm{As}(\mathrm{III})$ by synthetic birnessite is coupled with the reductive dissolution of the $\mathrm{MnO}_{2}$ surface and results in the release of both $\mathrm{As}(\mathrm{V})$ and $\mathrm{Mn}(\mathrm{II})$ to solution at low $\mathrm{pH}$ $(20,22)$. The net stoichiometry of the reaction is

$$
\mathrm{MnO}_{2}+\mathrm{H}_{3} \mathrm{AsO}_{3}+2 \mathrm{H}^{+}=\mathrm{Mn}^{2+}+\mathrm{H}_{3} \mathrm{AsO}_{4}+\mathrm{H}_{2} \mathrm{O}
$$

Recent work by Nesbitt et al. (19) usingX-ray photoelectron spectroscopy (XPS) has shown that the oxidation of As(III) by the synthetic $7 \AA$ birnessite surface proceeds by a twostep pathway, involving the reduction of $\mathrm{Mn}(\mathrm{IV})$ to $\mathrm{Mn}(\mathrm{III})$

$$
2 \mathrm{MnO}_{2}+\mathrm{H}_{3} \mathrm{AsO}_{3}=2 \mathrm{MnOOH}^{*}+\mathrm{H}_{3} \mathrm{AsO}_{4}
$$

where $\mathrm{MnOOH}^{*}$ is a $\mathrm{Mn}(\mathrm{III})$ intermediate reaction product. The reaction in eq 2 is followed by the reaction of $\mathrm{As}(\mathrm{III})$ with $\mathrm{MnOOH}^{*}$

$$
\begin{aligned}
& 2 \mathrm{MnOOH}^{*}+\mathrm{H}_{3} \mathrm{AsO}_{3}+4 \mathrm{H}^{+}= \\
& 2 \mathrm{Mn}^{2+}+\mathrm{H}_{3} \mathrm{AsO}_{4}+3 \mathrm{H}_{2} \mathrm{O}
\end{aligned}
$$

An additional reaction could includethe adsorption of $\mathrm{As}(\mathrm{V})$ by the $\mathrm{MnO}_{2}$ surface

$$
2 \mathrm{Mn}-\mathrm{OH}+\mathrm{H}_{3} \mathrm{AsO}_{4}=(\mathrm{MnO})_{2} \mathrm{AsOOH}+2 \mathrm{H}_{2} \mathrm{O}
$$

where $\mathrm{Mn}-\mathrm{OH}$ represents a reactive hydroxyl group on the $\mathrm{MnO}_{2}$ surface and $(\mathrm{MnO})_{2} \mathrm{AsOOH}$ represents the $\mathrm{As}(\mathrm{V})$ surface complex. Though considerableeffort has yielded mechanistic details about the reactions of $\mathrm{As}(\mathrm{III})$ with $\mathrm{MnO}_{2}$ compounds, very little information is available about the formation of $\mathrm{As}(\mathrm{V})$ complexes after the oxidation of As(III).

To provide new insight into the reaction of As(III) with a representative $\mathrm{Mn}$ oxide, the objectives of this study were (1) to investigate the reactivity of $\mathrm{As}(\mathrm{III})$ with a synthetic $\mathrm{MnO}_{2}$ compound, using a stirred reactor combined with an 
advanced technique for dissolved $\mathrm{As}(\mathrm{III}) / \mathrm{As}(\mathrm{V})$ speciation, and (2) to use EXAFS spectroscopy to examine the coordination environment of the surface complexes formed when $\mathrm{As}(\mathrm{III})$ and $\mathrm{As}(\mathrm{V})$ are reacted with $\mathrm{MnO}_{2}$. This investigation was designed to link the findings of previous work (18-21) with new information derived from EXAFS spectroscopy.

\section{Materials and Methods}

Synthesis of $\mathbf{M n O}_{2}$. Potassium birnessite, a $7 \AA$ manganite, was synthesized following the procedures of McKenzie (26). Heated $0.4 \mathrm{M} \mathrm{KMnO}_{4}$ was prepared in a $1 \mathrm{~L}$ glass separatory funnel with an outlet flow preset and clamped to deliver 950 $\mathrm{mL} / \mathrm{min}$. Another $250 \mathrm{~mL}$ separatory funnel containing heated $\left(60^{\circ} \mathrm{C}\right)$ concentrated $\mathrm{HCl}$ (Baker, Instrapure) with an outlet flow preset and clamped to deliver $66 \mathrm{~mL} / \mathrm{min}$ was used. Mixing of the $0.4 \mathrm{M} \mathrm{KM} \mathrm{NO}_{4}$ with concentrated $\mathrm{HCl}$ was initiated by simultaneously unclamping the separatory funnels and collecting the resulting mixture in a $2.5 \mathrm{~L}$ glass beaker on a stirring hot plate heated at $90^{\circ} \mathrm{C}$ in a fumehood. After stirring for an additional $10 \mathrm{~min}$ at $90^{\circ} \mathrm{C}$, the mixture was allowed to cool to room temperature $\left(23^{\circ} \mathrm{C}\right)$, transferred to $250 \mathrm{~mL}$ polycarbonate centrifuge bottles, and repeatedly rinsed with deionized (DI) water. After 10 rinse cycles the potassium concentration in the rinseate was analyzed by acetylene flame atomic absorption spectrometry (AAS) and was below $0.005 \mathrm{mM} \mathrm{K}$. The $\mathrm{MnO}_{2}$ solids were air-dried and gently crushed and sieved to pass a $100 \mu \mathrm{m}$ sieve.

Thesynthetic $\mathrm{MnO}_{2}$ was characterized by several methods, including the determination of the $\mathrm{K}$ content of the solid $\mathrm{MnO}_{2}$, X-ray diffraction (XRD) analysis, and specific surface area. The $\mathrm{K}$ content was determined by dissolving $0.100 \mathrm{~g}$ of $\mathrm{MnO}_{2}$ in $20 \mathrm{~mL}$ of $2.2 \mathrm{M} \mathrm{H}_{2} \mathrm{O}_{2} / 0.5 \mathrm{M} \mathrm{HCl}$ followed by flame AAS analysis. The specific surface area was determined by single-point Brunauer-Emmett-Teller (BET) $\mathrm{N}_{2}$ adsorption using a Quantisorb Jr. flow-through surface area analyzer (Quantichrome Corp.). The crystallinity of the material was analyzed by powder X-ray diffraction analysis using $\mathrm{Cu} \mathrm{K \alpha}$ radiation.

Reaction of As(III) with Synthetic $\mathbf{M n O}_{2}$. The reaction of As(III) with $\mathrm{MnO}_{2}$ was investigated using rotating propellerstirred reactor in a temperature controlled bath $\left(22^{\circ} \mathrm{C}\right)$. A 1 $\mathrm{L}$ glass beaker containing either 40 or $100 \mathrm{mg}$ of synthetic $\mathrm{MnO}_{2}$ and $400 \mathrm{~mL}$ of $0.10 \mathrm{M} \mathrm{NaCl}$ ( 100 or $250 \mathrm{mg} \mathrm{L}^{-1} \mathrm{MnO}_{2}$ ) was stirred and equilibrated for $1 \mathrm{~h}$ without gas atmospheric control. The $\mathrm{pH}$ of the suspensions was measured with a Corning semi-micro glass combination electrode and a Corninglon Analyzer 150. For all experiments, thesuspension $\mathrm{pH}$ was maintained at 6.50, which was near the ambient $\mathrm{pH}$ of the suspensions. A stock solution containing $13.33 \mathrm{mM}$ $\mathrm{As}$ (III) was prepared by dissolving $0.867 \mathrm{~g}$ of $\mathrm{NaAsO}_{2}$ (Sigma) in $500 \mathrm{~mL}$ of DI water.

The batch reaction was initiated by the addition of $3 \mathrm{~mL}$ of $13.33 \mathrm{mM} \mathrm{As}(\mathrm{III})$ to the suspension, making the solution $0.10 \mathrm{mM}$ As(III). The reaction was monitored by filtration of $2 \mathrm{~mL}$ aliquots with $0.1 \mu \mathrm{m}$ membranes and $\mathrm{As}(\mathrm{III}) / \mathrm{As}(\mathrm{V})$ speciation analysis by high-performance liquid chromatography atomic absorption spectrophotometry (HPLC-HGAAS) (32). This method separates As(III) and As(V) with a Dionex AS11 Ionpac anion exchange column in-line with a continuous flow-through hydride generator (Varian VGA 76) and a PerkinElmer 3030B AA spectrometer monitoring the 193.7 $\mathrm{nm}$ wavelength. At the end of the stirred reaction experiments $(t=48 \mathrm{~h})$, soluble $\mathrm{Mn}$ was measured by inductively coupled plasma emission spectrometry (ICP-ES) at $257.610 \mathrm{~nm}$.

EXAFS and Molecular Modeling Analysis. Samples of synthetic $\mathrm{MnO}_{2}$ treated with $\mathrm{As}(\mathrm{III})$ were prepared for EXAFS analysis by reacting $1.00 \mathrm{~g}$ of synthetic $\mathrm{MnO}_{2}$ with $1.0 \mathrm{~L}$ of $1.0 \mathrm{mM} \mathrm{As}(\mathrm{III})$ in $0.10 \mathrm{M} \mathrm{NaCl}$ in a stirred $2 \mathrm{~L}$ glass beaker for $24 \mathrm{~h}$ at $\mathrm{pH}$ 6.50. An identical preparation was made using $\mathrm{As}(\mathrm{V})$. After settling, the $\mathrm{As}(\mathrm{III}) / \mathrm{As}(\mathrm{V})$ speciation in the overlying solution was analyzed by HPLC-HGAAS, and the solids were collected and rinsed with DI water on ashless filter paper. The As(III)- and As(V)-treated samples were stored as wet pastes on the filter paper for 3 days prior to EXAFS analysisin sealed polycarbonatetest tubes. Oxidation of $A s(I I I)$ was not a concern because this reaction had gone to completion in the initial sample preparation. Solutions of $1.0 \mathrm{mM} \mathrm{As}(\mathrm{III})$ and $1.0 \mathrm{mM} \mathrm{As}(\mathrm{V})$ were also analyzed to examinetheX-ray absorption edgefeatures of solubleAs(III) and $\mathrm{As}(\mathrm{V})$ and background contributions to EXAFS spectra.

EXAFS and XANES spectra were collected at the Stanford Synchrotron Radiation Laboratory (SSRL) on beamline 4-3 using $\mathrm{Si}$ (220) monochromator and a 13element germanium semiconductor detector (33). The K edge of As (11 $867 \mathrm{eV}$ ) was examined using an energy range of $11667-12867 \mathrm{eV}$, and at least 5 individual scans were collected for each sample. TheXANES region of theX-ray absorption spectrum (11 860$11900 \mathrm{eV}$ ) was analyzed by normalizing the fluorescence data to the edge-jump height and calculating the first derivative of the spectra.

The EXAFS data were analyzed using EXAFSPAK software (34). Individual scans were averaged, and the background X-ray absorbance was removed by fittinga linear polynomial equation through the pre-edge region. This was followed by fitting a spline function through the extended X-ray absorption region of the spectra (11 920-12 $867 \mathrm{eV}$ ) to isolate the oscillations which arethe result of backscattering of outgoing photoelectrons by coherent shells of atoms around the central As atom. The EXAFS spectra were normalized using a Victoreen polynomial function and transformed from $\mathrm{eV}$ to $\AA^{-1}$ units to produce the EXAFSfunction $(\chi(\mathrm{k}))$, where $\left(\AA^{-1}\right)$ is the photoelectron wave vector. The $\chi(\mathrm{k})$ function was then weighted by $\mathrm{k}^{3}$ and truncated leaving a $\mathrm{k}$ range of 3.65-15.52 $\AA^{-1}$ for fitting. Fourier transformation (FT) of the ${ }^{3}$-weighted $\chi(\mathrm{k})$ function $\left(\chi(\mathrm{k}) \mathrm{k}^{3}\right)$ in $\mathrm{k}$ space $\left(\AA^{-1}\right)$ yielded the radial structure function (RSF) in R space $(\AA)$, where peaks correspond to atomic shells around the As atom (e.g., As-O and $\mathrm{As}-\mathrm{Mn}$ ).

The theoretical EXAFS expression was fit to experimental data usingEXAFSPAK. TheAs-O and As-MnRSF peaks were isolated by selecting the $R$ window at theminimum amplitude points around peaks. The As- $\mathrm{O}$ and $\mathrm{As}-\mathrm{Mn} \mathrm{R}$ windows were 0.988-1.618 and 2.535-3.073 $\AA$, respectively for both As(III)and $\mathrm{As}(\mathrm{V})$-treated $\mathrm{MnO}_{2}$. Peaks in the RSF were first analyzed individually, followed by analysis of a composite $R$ window of $0.988-3.073 \AA$ which contained both As-O and As- $M n$ shells. Individual $\mathrm{As}-\mathrm{O}$ and $\mathrm{As}-\mathrm{Mn} \mathrm{R}$ windows and the composite As-O + As-Mn R window were back-Fourier transformed to produce the Fourier filtered EXAFS functions. Fourier filtered experimental EXAFS data were fit with a theoretical EXAFS equation in which the coordination number $(\mathrm{N})$, the interatomic distance $(\mathrm{R})$, the Debye-Waller term $\left(\sigma^{2}\right)$, and the energy offset $\left(\mathrm{E}_{0}\right)$ were used as adjustable parameters to give the best fit to the Fourier filtered data. Phase and amplitude functions for the absorber and backscatterers were defined using single-scattering curved wave assumptions in the FEFF 7.0 model $(35,36)$. Values of N, R, $\sigma^{2}$, and $\mathrm{E}_{0}$ which were fitted to Fourier filtered data were then used as starting values to model the raw unfiltered EXAFS data. Error estimates of the fitted parameters were $\mathrm{R} \pm 0.02$ $\AA, \mathrm{N} \pm 20 \%$, and $\sigma^{2} \pm 20-30 \%$.

Molecular modeling calculations were performed on representative $\mathrm{Mn}-\mathrm{As}-\mathrm{O}$ clusters using PC Spartan Pro and perturbed Becke-Perduedensity functional calculations with full numerical polarization. In most cases, the results were similar to PM3 semiempirical and 6-31G* Hartree-Fock methods. The clusters used to simulate the As(V) surface complex on $\mathrm{MnO}_{2}$ involved the construction of a $\mathrm{Mn}(\mathrm{OH})_{6}$ octahedron (or two for a binuclear complex) with 1, 2, or 3 of the hydroxyls replaced with an $\mathrm{HAsO}_{4}{ }^{2-}$ group. Complete 


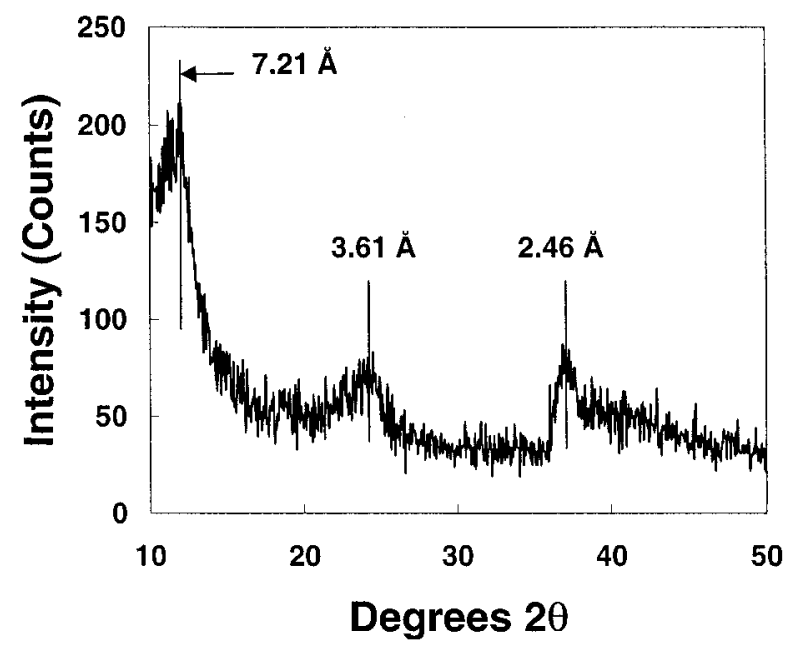

FIGURE 1. X-ray pow der diffraction pattern of synthetic birnessite.

protonation of the complex was used to minimize the net charge on the complex. The oxidation state of $\mathrm{Mn}$ was adjusted in the calculation between $\mathrm{Mn}(\mathrm{II}), \mathrm{Mn}(\mathrm{III})$, and $\mathrm{Mn}$ (IV) by changing the total number of electrons in the system. The attachment of $\mathrm{As}(\mathrm{V})$ (e.g., monodentate vs bidentate) was also specified, and the most stable atomic configuration and interatomic distances were determined.

\section{Results and Discussion}

Synthetic $\mathbf{M n O}_{2}$. Three dominant reflections at 2.46, 3.61, and $7.21 \AA$ were observed in the XRD pattern (Figure 1) consistent with peaks observed for synthetic birnessite by others $(18,21,27)$. The synthetic $\mathrm{MnO}_{2}$ solid had a composition of $4.9 \% \mathrm{~K}, 50.5 \% \mathrm{Mn}, 15.0 \% \mathrm{H}_{2} \mathrm{O}$, and $29.6 \% \mathrm{O}(\% \mathrm{w} / \mathrm{w})$. This composition is similar to a previous birnessite material used by Moore et al. (18) who investigated As(III) oxidation by synthetic birnessite which contained $1.7 \%$ and $8.2 \% \mathrm{~K}$ by weight. The $\mathrm{MnO}_{2}$ had a specific surface area of $32.0 \mathrm{~m}^{2} \mathrm{~g}^{-1}$, measured by BET $\mathrm{N}_{2}$ analysis similar to the $\mathrm{MnO}_{2}$ material reported previously (26).

Batch Reactor Study. The oxidation of As(III) by synthetic $\mathrm{MnO}_{2}$ at two different solid concentrations at $\mathrm{pH} 6.50$ is shown in Figure 2. Rapid uptake of $\mathrm{As}(\mathrm{III})$ by $\mathrm{MnO}_{2}$ is apparent as well as formation of both soluble and adsorbed $\mathrm{As}(\mathrm{V})$. Dissolved As(III) was below the detection limit at $1 \mathrm{~h}$ in the higher (250 mg L-1) $\mathrm{MnO}_{2}$ suspension density, and approximately $30 \%$ of the original As(III) added was unrecoverable and presumed to be adsorbed As(V) (Figure 2b). At thetermination of the reaction (48 h), the Assurface coverage on $\mathrm{MnO}_{2}$ achieved was 253 and $121 \mathrm{mmol} \mathrm{As} \mathrm{kg}{ }^{-1}$ (7.91 and $3.78 \mu \mathrm{mol} \mathrm{m}{ }^{-2} \mathrm{As}$ ) in the $100 \mathrm{mg} \mathrm{L}^{-1} \mathrm{MnO}_{2}$ and $250 \mathrm{mg} \mathrm{L}^{-1}$ $\mathrm{MnO}_{2}$ systems, respectively. Chromatograms collected from the $100 \mathrm{mg} \mathrm{L}^{-1} \mathrm{MnO}_{2}$ reaction provided direct, simultaneous speciation of $\mathrm{As}(\mathrm{III})$ and $\mathrm{As}(\mathrm{V})$ in solution (Figure 3 ). The As(III) solution concentration timeseries data wereanalyzed by fitting a first-order rate equation to the $0-0.5$ and $0-2 \mathrm{~h}$ portions of the $100 \mathrm{mg} \mathrm{L}^{-1} \mathrm{MnO}_{2}$ and $250 \mathrm{mg} \mathrm{L}^{-1} \mathrm{MnO}_{2}$ systems, respectively (Figure 4). Efforts to fit first-order rate equations to theentiretimeseries $(0-48 \mathrm{~h})$ wereunsuccessful. Therefore, only the initial fast As(III) uptake reaction data was used for analysis. The rate of As(III) uptake at the 100 and $250 \mathrm{mg} \mathrm{L}^{-1}$ suspension densities was first-order dependent on $[\mathrm{As}(\mathrm{III})]$; however, the slopes in Figure 4 were not proportional to suspension density. This suggested that the measured $A s(I I I)$ uptake reaction rate was not an elementary ratebut an apparent rate which was complicated by other surface reactions such as $\mathrm{MnO}_{2}$ surface alterations during the As(III) oxidation reaction or competition between with $\mathrm{As}(\mathrm{V})$ product for binding sites.

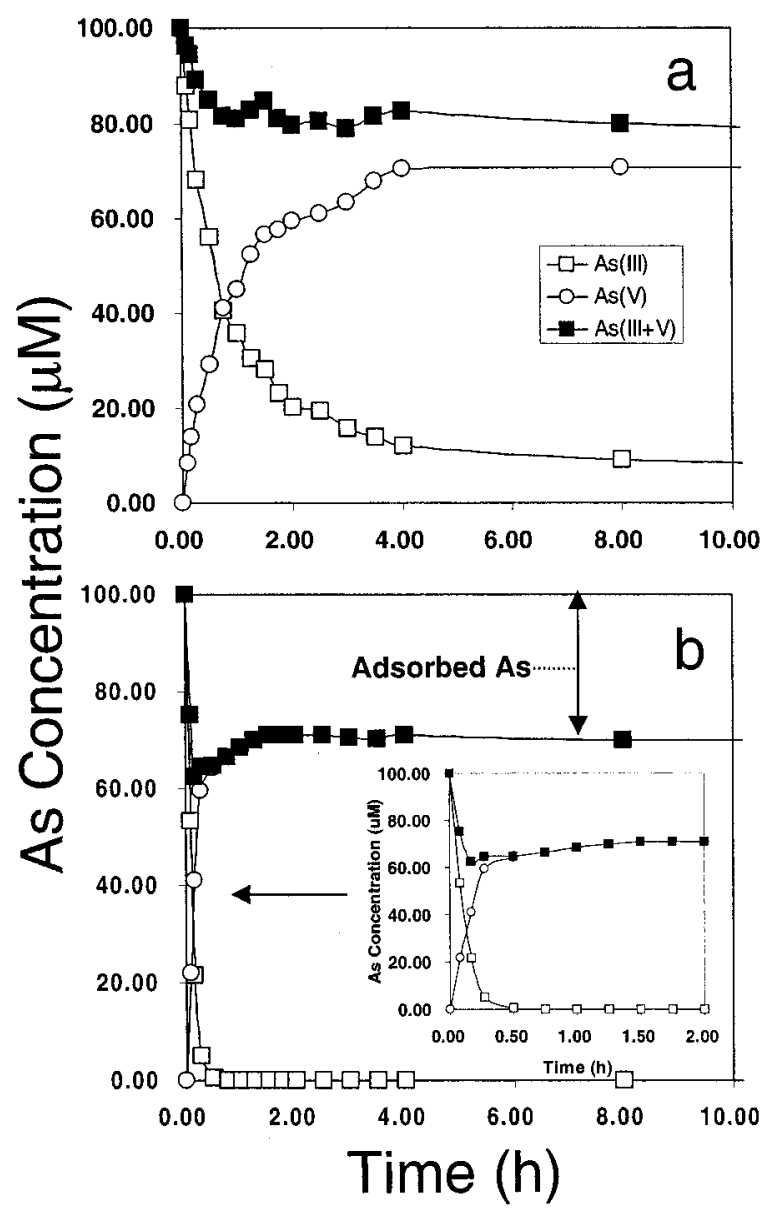

FIGURE 2. Speciation of dissolved As(III)/(V) and total As(III) + (V) recovery during the reaction of $0.10 \mathrm{mM} \mathrm{As(III)}$ with synthetic birnessite $\left(\mathrm{MnO}_{2}\right)$ as a function of time: (a) $100 \mathrm{mg} \mathrm{L}^{-1} \mathrm{MnO}_{2}$ and (b) $250 \mathrm{mg} \mathrm{L}^{-1} \mathrm{MnO}_{2}$ with inset showing expanded $0-2 \mathrm{~h}$ region of data.

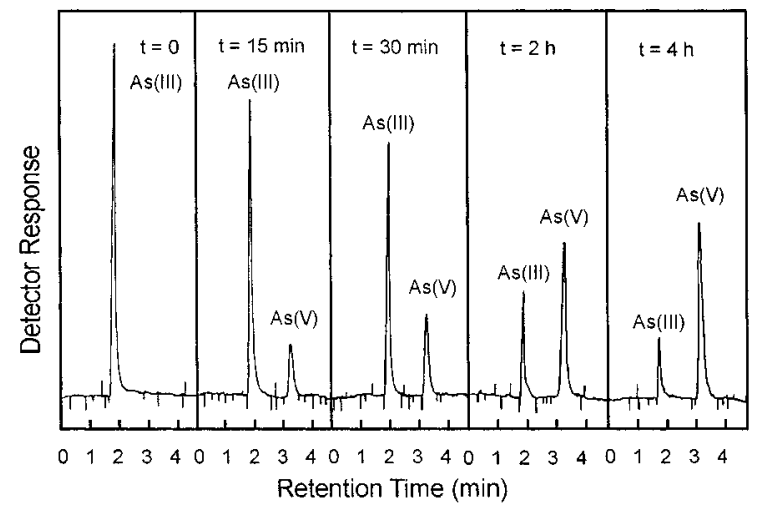

FIGURE 3. HPLC-HGAAS chromatograms showing the detection method for As(III)/(V) speciation during the $0-4 \mathrm{~h}$ time course of the reaction of $0.10 \mathrm{mM} \mathrm{As}$ (III) w ith synthetic birnessite $100 \mathrm{mg} \mathrm{L}^{-1}$ $\mathrm{MnO}_{2}$.

The dissolved $\mathrm{Mn}^{2+}$ concentration was 9.09 and $5.10 \mu \mathrm{M}$ for the 100 and $250 \mathrm{mg} \mathrm{L}^{-1} \mathrm{MnO}_{2}$ systems, respectively, showing that the production of dissolved $\mathrm{Mn}^{2+}$ was not stoichiometrically related to As(III) oxidation in our experiments. The nonstoichiometric relationship between As(III) oxidation and release of dissolved $\mathrm{Mn}$ (II) is evidence for the formation of $\mathrm{Mn}(\mathrm{III})$, which remains in the $\mathrm{MnO}_{2}$ crystal structure as the product of a one electron-transfer reaction step (eq 2) (19). Other previous work, however, has found a nearly stoichiometric association between As(III) oxidation 


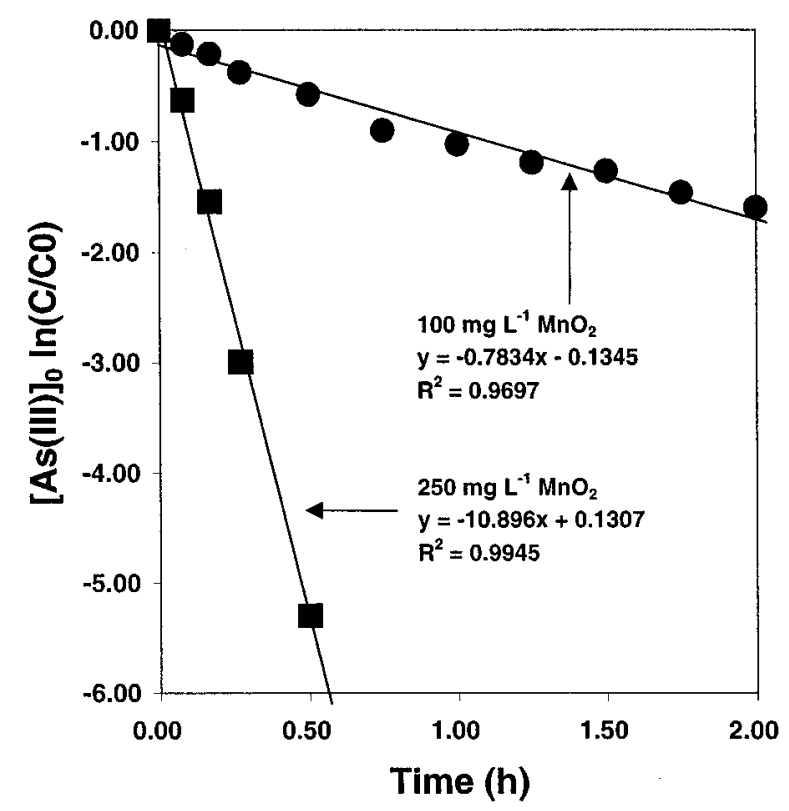

FIGURE 4. Linear regression analysis of normalized As(III) uptake by synthetic birnessite $\left(\mathrm{M} \mathrm{nO}_{2}\right.$ ) at tw 0 suspension densities (100 and $250 \mathrm{mg} \mathrm{L}^{-1} \mathrm{MnO}_{2}$ ).
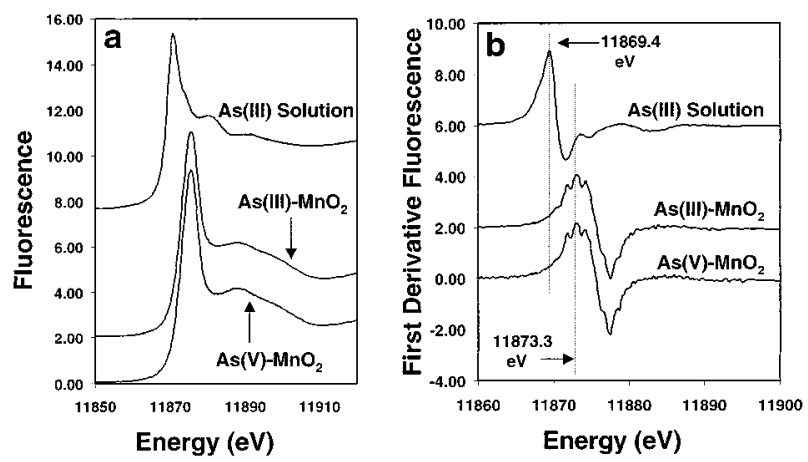

FIGURE 5. K-edge XANES spectra (a) and first derivatives of the spectra (b) for the As(III)- and As(V)-treated synthetic birnessite $\left(\mathrm{MnO}_{2}\right)$ and a solution of $1.0 \mathrm{mM} \mathrm{As}(\mathrm{III})(\mathrm{pH} \mathrm{6.5)}$. Also show $\mathrm{n}$ are the maxima in the derivative curves at $11869.4 \mathrm{eV}$ (As(III)) and $11873.3 \mathrm{eV}(\mathrm{As}(\mathrm{V}))$.

to $\mathrm{As}(\mathrm{V})$ and release of dissolved $\mathrm{Mn}$ at $\mathrm{pH} 4$ (20). Oxidation of $\mathrm{Cr}(\mathrm{III})$ to $\mathrm{Cr}(\mathrm{VI})$ by $\mathrm{MnO}_{2}$ at $\mathrm{pH} 3.0$ and 5.0 resulted in 1.5 $\mathrm{Mn}^{2+}$ formed for each $\mathrm{Cr}(\mathrm{III})$ oxidized (27). At pH 6.50 in the present study, however, the $\mathrm{MnO}_{2}$ particle surface contains negatively charged surface functional groups $\left(\equiv \mathrm{Mn}-\mathrm{O}^{-}\right)$; thus, soluble $\mathrm{Mn}^{2+}$ formed by reductive dissolution of $\mathrm{MnO}_{2}$ remains adsorbed on the negatively charged surface.

EXAFS and XANES Analysis. Synthetic $\mathrm{MnO}_{2}$ was treated with both $\mathrm{As}(\mathrm{III})$ and $\mathrm{As}(\mathrm{V})$ for EXAFS and XANES analysis. The K-edge XANES spectra and their first derivatives for the As-treated $\mathrm{MnO}_{2}$ and a $1.0 \mathrm{mM} \mathrm{As}(\mathrm{III})$ solution are shown in parts $a$ and $b$ of Figure 5. The K-edge data exhibit an absorption edge difference of $3.9 \mathrm{eV}$ (or $1.95 \mathrm{eV}$ per unit oxidation state change) between the As(III) solution and the $\mathrm{As}(\mathrm{III})$ - and $\mathrm{As}(\mathrm{V})$-treated $\mathrm{MnO}_{2}$ samples (Figure $5 \mathrm{~b}$ ). Noticeable differences are evident in the first derivative data for $\mathrm{As}$ (III) solution and As-treated $\mathrm{MnO}_{2}$ samples, including the multiple peak pattern for As-treated $\mathrm{MnO}_{2}$ samples. The first derivative data indicate that a nearly identical structural and electronic environment exists in the As(III)- and As(V)-treated $\mathrm{MnO}_{2}$ samples. This is directevidencethat the As(III) oxidized by $\mathrm{MnO}_{2}$ solids was adsorbed as As(V).

The theoretical EXAFS functions $\left(\chi(k) k^{3}\right)$ for As(III)- and $\mathrm{As}(\mathrm{V})$-treated $\mathrm{M} \mathrm{nO}_{2}$ and the $1.0 \mathrm{mM} \mathrm{As}(\mathrm{V})$ solution are shown

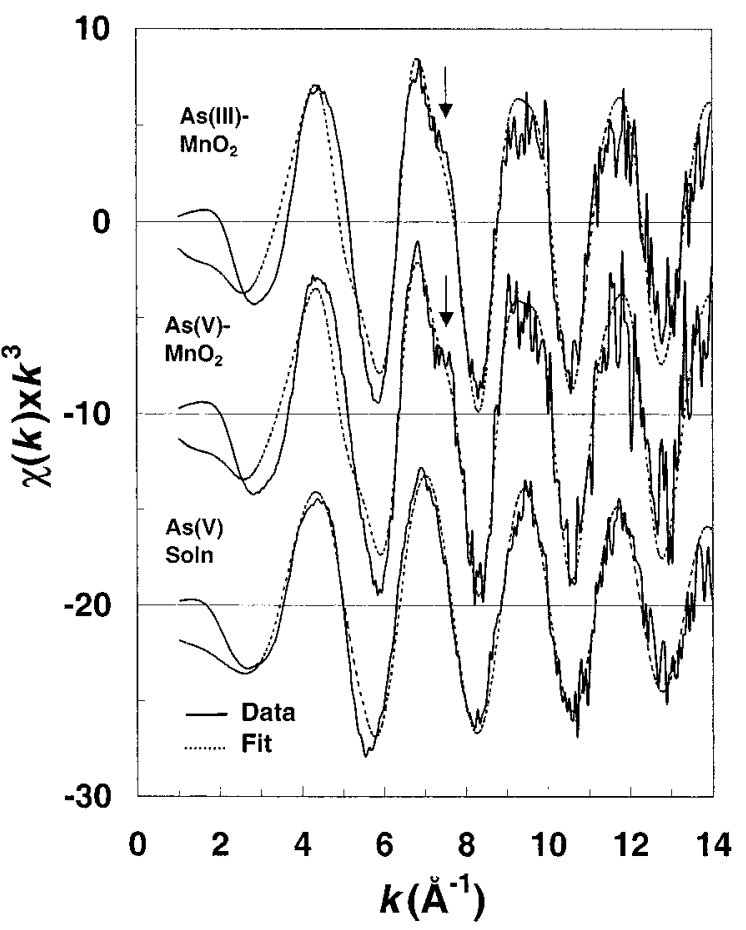

FIGURE 6. Experimental, unfiltered EXAFS data for As(III)- and As(V)treated synthetic birnessite $\left(\mathrm{MnO}_{2}\right)$ at $\mathrm{pH} 6.5$ and a solution of 1.0 mM As(V) (solid lines). Also show $n$ is the theoretical fit (dashed lines) of the EXAFS function $\left(\alpha(k) k^{3}\right)$ which contains As-0 and As $-M n$ shell contributions As-treated synthetic birnessite. Arrow $s$ indicate the sine wave beat-pattern contribution from the As-M n shell.

TABLE 1. EXAFS Parameters Optimized Using EXAFSPAK for As(III)- and As(V) Treated Synthetic $\mathrm{MnO}_{2}$ and $1.0 \mathrm{MM} \mathrm{As}(\mathrm{V})$ Solution

\begin{tabular}{clcccc} 
sample & \multicolumn{1}{c}{ shell } & $\boldsymbol{N}^{\mathbf{a}}$ & $\boldsymbol{R}(\mathbf{A})$ & $\boldsymbol{\sigma}^{2}$ & $\boldsymbol{E}_{\mathbf{0}}$ \\
$\mathrm{As}(\mathrm{III})-\mathrm{MnO}_{2}$ & $\mathrm{As}-\mathrm{O}$ & 3.89 & 1.69 & $1.00 \times 10^{-3}$ & -1.75 \\
& $\mathrm{As}-\mathrm{Mn}$ & 2.01 & 3.22 & $6.02 \times 10^{-3}$ & -1.75 \\
$\mathrm{As}(\mathrm{V})-\mathrm{MnO}_{2}$ & $\mathrm{As}-\mathrm{O}$ & 3.90 & 1.69 & $7.00 \times 10^{-4}$ & -1.56 \\
& $\mathrm{As}-\mathrm{Mn}$ & 1.99 & 3.22 & $4.95 \times 10^{-3}$ & -1.56 \\
$1.0 \mathrm{mM} \mathrm{As}(\mathrm{V})$ & $\mathrm{As}-\mathrm{O}$ & 4.00 & 1.69 & $2.00 \times 10^{-3}$ & 0.02
\end{tabular}

${ }^{a} N=$ coordination number, $R=$ interatomic distance (error $= \pm 0.02$ $\AA$ ), $\sigma^{2}=$ Debye-Waller term, $E_{0}=$ energy offset (threshold $E_{0}$ shift in $\mathrm{eV}$, used for all shells).

in Figure 6. The $\chi(\mathrm{k}) \mathrm{k}^{3}$ EXAFS expression was fit to the experimental data, and the resulting adjustable parameters $\left(\mathrm{N}, \mathrm{R}, \sigma^{2}\right.$, and $\left.\mathrm{E}_{0}\right)$ for $\mathrm{As}(\mathrm{III})$ - and $\mathrm{As}(\mathrm{V})$-treated $\mathrm{MnO}_{2}$ and the 1.0 mM As(V) solution sample are given in Table 1. The fitted lines (dotted, Figure 6) for $\mathrm{As}(\mathrm{III})$ - and $\mathrm{As}(\mathrm{V})$-treated $\mathrm{MnO}_{2}$ represent a composite sine wave with a primary contribution from the first shell of $\sim 3.90 \mathrm{O}$ atoms surrounding the As atom in tetrahedral symmetry (As-O shell) at an average distance of $1.69 \AA$. Smaller, but distinct, contributions from $\sim 2.00 \mathrm{Mn}$ atoms at $3.22 \AA$ from the As atom are also components in the fits to $\mathrm{As}(\mathrm{III})$ - and $\mathrm{As}(\mathrm{V})$-treated $\mathrm{MnO}_{2}$ samples. The contribution of the second shell of $\mathrm{Mn}$ atoms results in a noticeable second harmonic beat (arrows, Figure 6) in the EXAFS data.

TheAs-O interatomic distancewas $1.69 \AA$ for both As(III)and $\mathrm{As}(\mathrm{V})$-treated $\mathrm{MnO}_{2}$ samples, which was $0.01-0.02 \AA$ greater than previously reported As-O interatomic distances for $\mathrm{As}(\mathrm{V})(37-39)$ but shorter than the 1.78-1.79 $\AA$ reported for $\mathrm{As}(\mathrm{III})(37,40)$. Both $\mathrm{As}(\mathrm{III})$ - and $\mathrm{As}(\mathrm{V})$-treated $\mathrm{MnO}_{2}$ samples were best described with an As-Mn shell at $3.22 \AA$ (Table 1). The Fourier transform of the data in Figure 6 


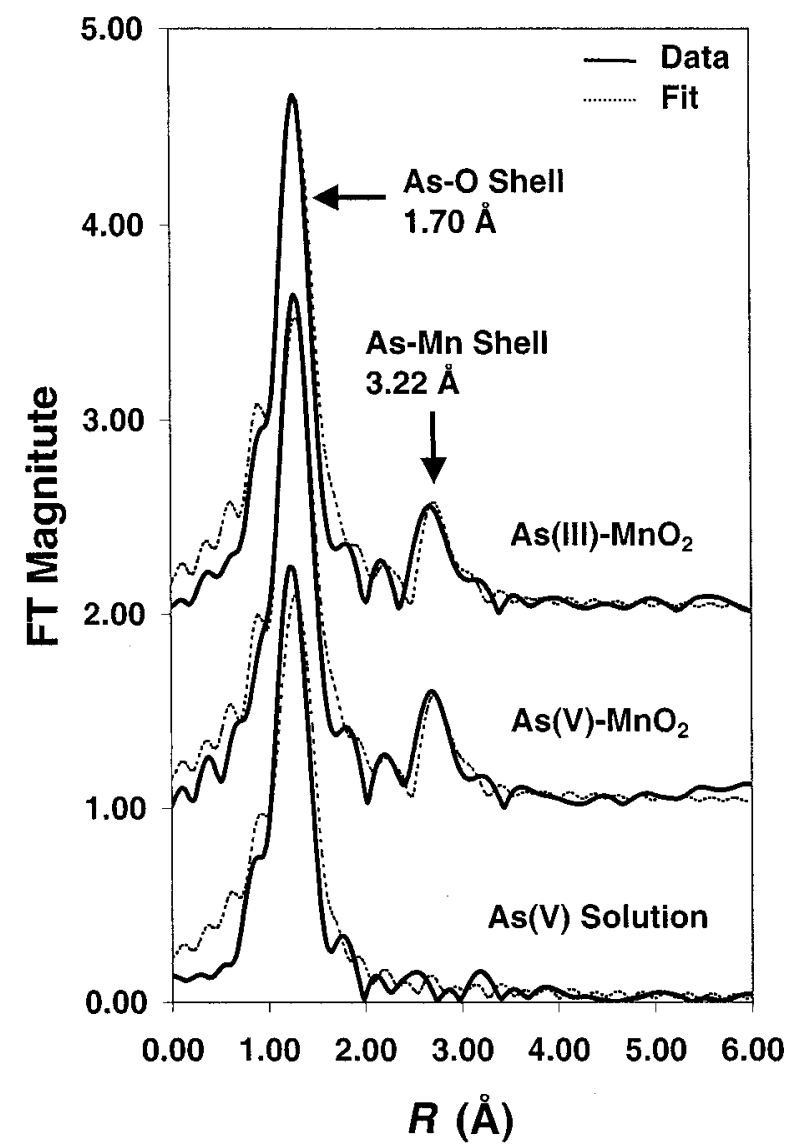

FIGURE 7. Radial structure functions (not phase corrected) for As(III)and $\mathrm{As}(\mathrm{V})$-treated synthetic birnessite $\left(\mathrm{MnO}_{2}\right)$ and $1.0 \mathrm{mM} \mathrm{As}(\mathrm{V})$ solution. Dashed lines are the fits to the experimental RSF data and peaks correspond to As- 0 and As-Mn atomic shells around the As atom.

resulted in a distinct second shell peak in the radial structure functions (RSF) (Figure 7). The RSF data in Figure 7 were not phase-corrected and appear shifted slightly (about - $0.45 \AA$ ) from interatomic distances fit by EXAFSPAK and in Table 1. The $A s(V)$ solution RSF gives an indication of $A s(V)$ which is not bound to the $\mathrm{MnO}_{2}$ solid phase with no As-Mn shell included in the fit. The As-Mn distance of $3.22 \AA$ is characteristic of double-corner sharing polyhedra, consistent with surface complexes of $\mathrm{As}(\mathrm{V})$ noted for Fe (hydr)oxides (38).

To help constrain As-Mn interatomic distances and identify the most likely oxidation state of $\mathrm{Mn}$ to which $\mathrm{As}(\mathrm{V})$ is complexed, molecular modeling calculations were applied to hypothetical As-M n clusters. Previous investigations have speculated that As(III)-treated birnessite may produce an $\mathrm{Mn}(\mathrm{II})-\mathrm{As}(\mathrm{V})$ solid phase of the form $\mathrm{Mn}_{3}\left(\mathrm{AsO}_{4}\right)_{2}$ (18). Because of theincreased ionic radius of the $\mathrm{Mn}(\mathrm{II})$ ion, longer As- $\mathrm{Mn}$ interatomic distances were calculated than were observed with EXAFS. For example, the As- $\mathrm{Mn}$ distance in a hypothetical $\mathrm{Mn}(\mathrm{II})$-containing $\mathrm{Mn}_{2}(\mathrm{OH})_{8}\left(\mathrm{AsO}_{4}\right)^{7-}$ cluster was $3.48 \AA$, which is $0.26 \AA$ longer than that observed by EXAFS. This narrows the As(V) product to a surface complex with either $\mathrm{Mn}(\mathrm{IV})$ or $\mathrm{Mn}$ (III) or some combination of these polyhedra. On the basis of this information, in combination with the fact that the exact same EXAFS-derived As-Mn interatomic distance was found for both As(III)- and As(V)treated $\mathrm{MnO}_{2}$ samples, it appears that $\mathrm{As}(\mathrm{V})$, either added as $\mathrm{As}(\mathrm{V})$ or formed from oxidation of $\mathrm{As}(\mathrm{III})$, results in a surface complex on predominantly $\mathrm{Mn}(\mathrm{IV})$ polyhedra within birnessite. The hypothetical $\mathrm{Mn}(\mathrm{IV})$-containing clusters, includingmonodentatemononuclear $\left(\mathrm{Mn}(\mathrm{OH})_{5}\left(\mathrm{HAsO}_{4}\right)^{3-}\right)$ and

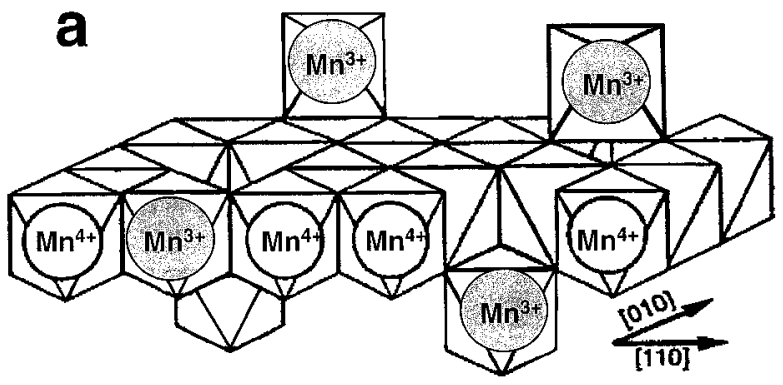

b

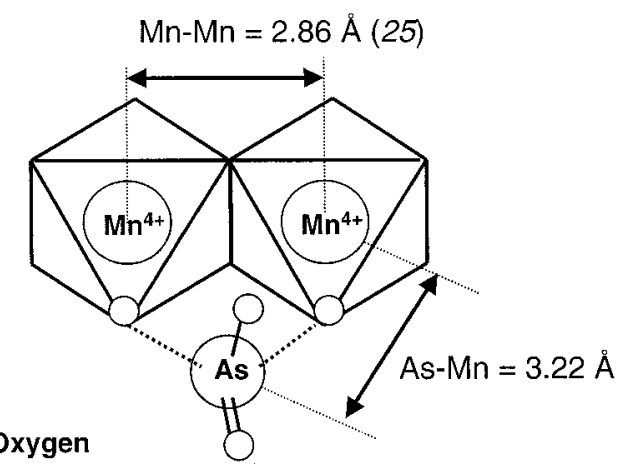

$O=$ Oxygen

FIGURE 8. Structural diagram of $\mathrm{MnO}_{2}$ crystallite corresponding to $7 \AA$ manganate (a) (adapted from M anceau et al. (25)) and possible linkages between an arsenate ion (As(V) tetrahedron) and a pair of edge-linked $\mathrm{MnO}_{6}$ octahedra (b). As-M interatomic distance was was $3.22 \AA$, suggesting a bidentate binuclear complex.

bidentate binuclear $\left(\mathrm{Mn}_{2}(\mathrm{OH})_{8}\left(\mathrm{AsO}_{4}\right)^{3-}\right)$, yielded $\mathrm{As}-\mathrm{Mn}$ distances which were more consistent with theEXAFS results.

On the basis of our results, a structural diagram of the most likely $\mathrm{As}(\mathrm{V})$ complex was developed (Figure 8). A birnessite crystallite showing linked $M n(I I I)$ and $M n(I V)$ octahedra and octahedral "holes" developed according to previously determined birnessite crystal structures $(25,30)$ is also included (Figure 8a). The proposed bidentate As(V) tetrahedron attachment mechanism to the birnessite crystal structure is supported experimentally by the presence of the As- $\mathrm{Mn}$ backscattering peak from a shell of $\mathrm{Mn}$ atoms at 3.22 $\AA$ for both $\mathrm{As}(\mathrm{III})$ - and $\mathrm{As}(\mathrm{V})$-treated $\mathrm{MnO}_{2}$. When $\mathrm{As}(\mathrm{V})$ is reacted with $\mathrm{Fe}$ hydroxides (goethite or ferrihydrite), the predominant $\mathrm{As}(\mathrm{V})$-Fe interatomic distances measured by EXAFS are between 3.24 and $3.28 \AA(38,39)$, indicative of a bidentate bridged complex linking adjacent apexes of two edge-sharing Fe octahedra. Considering the slightly smaller ionic radius of $\mathrm{Mn}(\mathrm{IV})(0.60 \AA)$ compared with $\mathrm{Fe}(\mathrm{III})$ (0.64 A) (41), our results are consistent with previously proposed As-Fe interatomic distances for $\mathrm{As}(\mathrm{V})$ complex formation on Fe oxides (38, 39).

Surface Coverage and Mn(II) Dissolution. Surface coveragesachieved for $\mathrm{As}(\mathrm{III})$ - and $\mathrm{As}(\mathrm{V})$-treated synthetic $\mathrm{MnO}_{2}$ were 266 and $50.7 \mathrm{mmol} \mathrm{kg}^{-1} \mathrm{As}$ (8.79 and $1.67 \mu \mathrm{mol} \mathrm{m}^{-2} \mathrm{As}$ ), respectively. The $\mathrm{As}(\mathrm{III})$-treated $\mathrm{MnO}_{2}$ sample analyzed by EXAFS had a comparable surface coverage to the $100 \mathrm{mg} \mathrm{L}^{-1}$ $\mathrm{MnO}_{2}$ batch reaction (7.91 $\mu \mathrm{mol} \mathrm{m} \mathrm{m}^{-2}$ As). The dramatic difference in As surface coverage between the As(III)- and $\mathrm{As}(\mathrm{V})$-treated $\mathrm{MnO}_{2}$ samples was caused by $\mathrm{As}(\mathrm{III})$-induced surface alteration during reductive dissolution of $\mathrm{MnO}_{2}$. Oscarson et al. (23) found that As(III) oxidation rateincreased and reached a maximum as the amount of $\mathrm{As}(\mathrm{III})$ was increased at a fixed $\mathrm{MnO}_{2}$ suspension density. It was postulated that a barrier was formed at or near the surface of theoxidethat prevented further reduction of thestructural $\mathrm{Mn}(\mathrm{IV})$ in the interior of crystallites (23). This is consistent with our results, which suggest that a surface layer of covalently bound $\mathrm{As}(\mathrm{V})$ forms on the reacted $\mathrm{MnO}_{2}$ surface which would limit further reaction of $\mathrm{MnO}_{2}$ with $\mathrm{As}(\mathrm{III})$. 
Dissolution of synthetic $\mathrm{MnO}_{2}$ by As(III) (18-21) and $\mathrm{Cr}(\mathrm{III})$ (27) releases $\mathrm{Mn}^{2+}$ ions, making fresh adsorption sites for $\mathrm{As}(\mathrm{V})$. XPS studies (19) also suggest the formation of $\mathrm{Mn}(\mathrm{III})$ from reductive dissolution of $\mathrm{MnO}_{2}$ during $\mathrm{As}(\mathrm{III})$ oxidation, allowing for the possible formation of $\mathrm{MnOOH}^{*}-\mathrm{As}(\mathrm{V})$ complexes.

The results of this investigation confirm the work of previous investigators who found that the reaction of As(III) with $\mathrm{MnO}_{2}$ results in $\mathrm{As}(\mathrm{III})$ oxidation to $\mathrm{As}(\mathrm{V})$. Though we have not addressed the initial formation of an $\mathrm{As}(\mathrm{III})-\mathrm{MnO}_{2}$ complex prior to oxidation in this study, presumably the As(III) species also forms an inner-sphere complex on $\mathrm{MnO}_{2}$ followed by electron transfer from $\mathrm{As}(\mathrm{III})$ to $\mathrm{Mn}(\mathrm{VI})$ and release of $A s(V)$ and $M n(I I)$. The majority of $A s(V)$ formed is released to the solution, with a significant fraction (between $20 \%$ and $30 \%$ depending on suspension density) being adsorbed on the $\mathrm{MnO}_{2}$ surface. The EXAFS results confirm that the $\mathrm{As}(\mathrm{V})$ surface complex on both the As(III)-altered $\mathrm{MnO}_{2}$ and unaltered $\mathrm{MnO}_{2}$ surfaces is an inner-sphere bidentate binuclear complex with an As-Mn interatomic distance of $3.22 \AA$. This research suggests that $\mathrm{MnO}_{2}$ materials used at near neutral $\mathrm{pH}$ in environmental remediation or drinking water filtering would play a beneficial role as both an efficient oxidant of $\mathrm{As}(\mathrm{III})$ and a sorbent for $\mathrm{As}(\mathrm{V})$.

\section{Acknowledgments}

This research was supported by the U.S. Department of Agriculture National Research Initiative Competitive Grants Program (Project No. 9604171).

\section{Literature Cited}

(1) Arsenic contamination of groundwater and its remedial action plan in West Bengal. AllH\&PH. In Consultation on arsenic in drinking water and resulting arsenic toxicity in India and Bangladesh; World Health Organization: New Delhi, India, 1997.

(2) Dhar, R. K.:Biswas, B. K.Samanta, G.; Mandal, B. K: Chakraborti, D.; Roy, S.; Jafar, A.; Islam, A.; Ara, G.; Kabir, S.; Khan, A. W.; Ahmed, S. A.; Hadi, S. A. Curr. Sci. 1997, 73, 48-59.

(3) Bhattacharya, P.; Chatterjee, D.; Jacks, G. Int. J. Water Res. Manage. 1997, 13, 79-92.

(4) Aurilio, A. C.; Mason, R. P.; Hemond, H. F. Environ. Sci. Technol. 1994, 28, 577-585.

(5) Hansen, S. H.; Larsen, E. H.; Pritzl, G.; Cornatt, C. J. Anal. At. Spectrom. 1992, 7, 629-634.

(6) Masscheleyn, P. H.; Delaune, R. D.; Patrick, W. H., Jr. J. Environ. Qual. 1991, 20, 522-527.

(7) Tye, C. T.; Haswell, S. J.; O’Neil, P.; Bancroft, K. C. C. Anal. Chim. Acta 1985, 169, 195-200.

(8) Sadiq, M.; Zaida, T. H.; Mian, A. A. Water, Air, Soil Pollut. 1983, 20, 369-377.

(9) Korte, N. E.; Fernando, Q. Crit. Rev. Environ. Control 1991, 21, $1-39$.

(10) Cherry, J. A.; Shaikh, A. U.; Tallman, D. E.; Nicholson, R. V. J. Hydrol. 1979, 43, 373-392.

(11) Ferguson, J. F.; Gavis, J. Water Res. 1972, 6, 1259-1274.

(12) Knowles, F. C.; Benson, A. A. TrendsBiochem. Sci. 1983, 8, 178180.
(13) Coddington, K. Toxicol. Environ. Chem. 1986, 11, 281-290.

(14) Manning, B. A.; Goldberg, S. Environ. Sci. Technol. 1997, 31, 2005-2011.

(15) Manning, B. A.; Goldberg, S. Soil Sci. 1997, 162, 886-895.

(16) Manning, B. A.; Suarez, D. L. Soil Sci. Soc. Am. J. 2000, 64, 128137.

(17) Foster, A. L.; Brown, G. E., Jr.; Parks, G. A. Environ. Sci. Technol. 1998, 32, 1444-1452.

(18) Moore, J. N.; Walker, J. R.; Hayes, T. H. Clays Clay Miner. 1990, $38,549-555$

(19) Nesbitt, H. W.; Canning, G. W.; Bancroft, G. M. Geochim. Cosmochim. Acta 1998, 62, 2097-2110.

(20) Scott, M. J.; Morgan, J. J. Environ. Sci. Technol. 1995, 29, 18981905.

(21) Oscarson, D. W.; Huang, P. M.; Liaw, W. K.; Hammer, U. T. Soil Sci. Soc. Am. J. 1983, 47, 644-648.

(22) Scott, M. J. Ph.D. Thesis, California Institute of Technology, Pasadena, CA, 1991.

(23) Oscarson, D. W.; Huang, P. M.; Liaw, W. K. Clays Clay Miner. 1981, 29, 219-225.

(24) Oscarson, D. W.; Huang, P. M.; Liaw, W. K. J. Environ. Qual. $1980,9,700-703$.

(25) Manceau, A.; Drits, V. A.; Silvester, E.; Bartoli, C.; Lanson, B. Structural mechanism of $\mathrm{CO}^{2+}$ oxidation by the phyllomanganate buserite. Am. Mineral. 1997, 82, 1150-1175.

(26) McKenzie, R. M. Aust. J. Soil Res. 1970, 8, 97-106.

(27) Fendorf, S. E.; Zasoski, R. J. Environ. Sci. Technol. 1992, 26, 79-85.

(28) McBride, M. B. Soil Sci. Soc. Am. J. 1987, 51, 1466-1472.

(29) Stone, A. T. In Rates of Soil Chemical Processes; Sparks, D. L., Suarez, D. L., Eds.; SSSA Special Publication: Madison, WI, 1991.

(30) Drits, V. A.; Silvester, E.; Gorshkov, A. I.; Manceau, A. Am. Mineral. 1997, 82, 946-961.

(31) Silvester, E.; Manceau, A.; Drits, V. A. Am. Mineral. 1997, 82, 962-978.

(32) Manning, B. A.; Martens, D. A. Environ. Sci. Technol. 1997, 31, $171-177$.

(33) Cramer, S. P.;Tench, O.; Yocum, M.; George, G. N. Nudl. Instrum. Methods Phys. Res., Sect. A 1988, 266, 586-591.

(34) George, G. N.; Pickering, I. J. EXAFSPAK: A Suite of Computer Programs for Analysis of X-ray Absorption Spectra. Stanford Synchrotron Radiation Laboratory: Stanford, CA, 1993.

(35) Mustre de Leon, J.; Rehr, J. J.; Zabinsky, S. I.; Albers, R. C. Phys. Rev. B: Condens. Matter 1991, 44, 4146-4149.

(36) Rehr, J. J.; Mustre de Leon, J.; Zabinsky, S. I.; Albers, R. C. J. Am. Chem. Soc. 1991, 113, 5135-5140.

(37) Foster, A. L.; Brown, G. E., Jr.; Tingle, T. N.; Parks, G. A. Am. Mineral. 1998, 83, 553-568.

(38) Waychunas, G. A.; Rea, B. A.; Fuller, C. C.; Davis, J. A. Geochim. Cosmochim. Acta 1993, 57, 2251-2269.

(39) Fendorf, S.; Eick, M. J.; Grossl, P.; Sparks, D. L. Environ. Sci. Technol. 1997, 31, 315-320.

(40) Manning, B. A.; Fendorf, S. E.; Goldberg, S. Environ. Sci. Technol. 1998, 32, 2383-2388.

(41) Handbook of Chemistry and Physics, 72nd ed.; Lide, Ed.; Chemical Rubber Company: Boca Raton, FL, 1991; p 12-8.

Received for review May 30, 2001. Revised manuscript received December 7, 2001. Accepted December 13, 2001.

ES0110170 